\title{
Molecular analysis of the microbial community structures in water-flooding petroleum reservoirs with different temperatures
}

\author{
L.-Y. Wang ${ }^{1}$, R.-Y. Duan ${ }^{1}$, J.-F. Liu ${ }^{1}$, S.-Z. Yang ${ }^{1}$, J.-D. Gu ${ }^{2}$, and B.-Z. Mu ${ }^{1}$ \\ ${ }^{1}$ State Key Laboratory of Bioreactor Engineering and Institute of Applied Chemistry, East China University of Science and \\ Technology, Shanghai 200237, China \\ ${ }^{2}$ School of Biological Sciences, The University of Hong Kong, Pokfulam Road, Hong Kong SAR, China
}

Correspondence to: B.-Z. Mu (bzmu@ecust.edu.cn)

Received: 6 April 2012 - Published in Biogeosciences Discuss.: 27 April 2012

Revised: 14 October 2012 - Accepted: 16 October 2012 - Published: 20 November 2012

\begin{abstract}
Analyses of microbial communities from six water-flooding petroleum reservoirs at temperatures from 21 to $63^{\circ} \mathrm{C}$ by $16 \mathrm{~S}$ rRNA gene clone libraries indicates the presence of physiologically diverse and temperature-dependent microorganisms in these subterrestrial ecosystems. In samples originating from high-temperature petroleum reservoirs, most of the archaeal sequences belong to thermophiles affiliated with members of the genera Thermococcus, Methanothermobacter and the order Thermoplasmatales, whereas bacterial sequences predominantly belong to the phyla Firmicutes, Thermotogae and Thermodesulfobacteria. In contrast to high-temperature petroleum reservoirs, microorganisms belonging to the Proteobacteria, Methanobacteriales and Methanomicrobiales were the most encountered in samples collected from low-temperature petroleum reservoirs. Canonical correspondence analysis (CCA) revealed that temperature, mineralization, ionic type as well as volatile fatty acids showed correlation with the microbial community structures, in particular members of the Firmicutes and the genus Methanothermobacter showed positive correlation with temperature and the concentration of acetate. Overall, these data indicate the large occurrence of hydrogenotrophic methanogens in petroleum reservoirs and imply that acetate metabolism via syntrophic oxidation may represent the main methanogenic pathway in high-temperature petroleum reservoirs.
\end{abstract}

\section{Introduction}

Petroleum reservoirs represent extreme anaerobic environments because of the temperature, pressure and salinity with multiphase fluids of oil, gas and water. Microorganisms in such subterranean ecosystems play an important role in energy flow and nutrients cycling. The microbial activity, in particular sulfidogenic prokaryotes not only cause issues such as reservoir souring and corrosion of drilling equipment with $\mathrm{H}_{2} \mathrm{~S}$ produced, but potentially can also be used to our advantage, e.g. microbial-enhanced energy recovery (MEER) applications. Extraction of currently usable energy from marginal petroleum reservoirs by microbial conversion of residual oil to methane (natural gas) has received renewed attention in the past decade (Parkes, 1999; Suflita et al., 2004; Gieg et al., 2008; Jones et al., 2008; Wang et al., 2010, 2011; Gray et al., 2011; Mbadinga et al., 2011, 2012; Li et al., 2012; Zhou et al., 2012). Microorganisms with diverse physiological and metabolic capabilities and phylogenetic affiliations have been recovered from oil reservoirs by culture-dependent and culture-independent approaches since the first sulfatereducing bacteria (SRB) was isolated from production water of an oil reservoir (Bastin et al., 1926). Though isolation efforts have identified numerous bacterial and archaeal species that are capable of mediating various metabolic processes occurring in oil fields, culture-independent $16 \mathrm{~S}$ rRNA genes and functional gene-based investigations have provided new information on the microbial community composition in such deep subsurface ecosystems (Li et al., 2010, 2011; Guan et al., 2012). 
Culture-independent surveys of high-temperature oil reservoirs have been conducted on continental and offshore oilfields (Orphan et al., 2000, 2003; Li et al., 2006, 2007a, b; Nazina et al., 2006; Dahle et al., 2008). Bacterial sequences affiliated with Firmicutes are the most frequently detected in these high-temperature oil reservoirs. In addition, moderately thermophilic members of the Bacteroidetes (genus Anaerophaga) have been identified in samples collected from the Troll oil formation in the North Sea. Methanogenic archaea, including methylotrophic, acetoclastic as well as $\mathrm{CO}_{2}$-reducing methanogens are the most common members in high-temperature oil reservoirs. Moreover, methanogenesis from acetate driven by syntrophic acetate oxidation has been documented in high-temperature reservoir (Nazina et al., 2006).

Compared with high-temperature oil reservoirs, only a few 16S-based analyses of the microbial community in lowtemperature oil reservoirs have been reported. The bacterial diversity in a low-temperature, low-salinity, non-water flooded oil reservoir (Pelican lake oil field) in western Canada was extremely low with only one phylotype related to the genus Arcobacter ( $\varepsilon$-Proteobacteria) (Grabowski et al., 2005). Several potentially metabolic active fermentative and/or acetogenic microorganisms, sulfide-oxidizers and sulfate-reducers were identified from a low-temperature oil reservoir in western Canada by $16 \mathrm{~S}$ rRNA gene clones library analysis (Voordouw et al., 1996).

The distribution of different microbial community structures in petroleum reservoirs depends entirely on their adaption to the in situ physical and chemical variables, including temperature, $\mathrm{pH}$, and salinity. In this report, the distribution of the microbial community in production water of several petroleum reservoirs at temperatures of $21,32,37,45,58$ and $63{ }^{\circ} \mathrm{C}$ was investigated by means of $16 \mathrm{~S}$ rRNA gene library analysis. Microbial community data were also correlated with environmental factors using canonical correspondence analysis (CCA).

\section{Materials and methods}

\subsection{Collection of samples and nucleic acid extraction}

All microbial nucleic acid samples originated from oil reservoir production waters sampled from six water-flooding oilfields in China, namely Zhan 3 (S1) block of Shengli oilfield, Baolige oilfield (Ba 18, S2; and Ba 51 block, S3), the Menggulin oilfield (S4), No. 7 (S5) and No. 6 (S6) blocks of Xinjiang Kelamayi oilfield. The Zhan 3 block of Shengli oilfield is located in the Shandong province of China. This oilfield has been water-flooded for over $20 \mathrm{yr}$. The depths of the sampling horizons are about $1300 \mathrm{~m}$ with a temperature of $63^{\circ} \mathrm{C}$. The porosity of the reservoir was $30 \%$, and air permeability was $0.8 \mu \mathrm{m}^{-3}$. The viscosity of the crude oil was $1720 \mathrm{mPas}$. The Menggulin (MGL) sandstone block in the MGL oilfield, as well as the Ba19 fault block in the Baolige oilfield (Huabei Oil Field) are all located in the central part of Inner Mongolia, China. The distance between the two blocks is approximately $50 \mathrm{~km}$. MGL oilfield has been water-flooded since 1989. Baolige oilfield has been water-flooded since 2001. The depths of the two blocks' horizons ranged from $800 \mathrm{~m}$ to $1500 \mathrm{~m}$, with a temperature of $37 \sim 58{ }^{\circ} \mathrm{C}$. The porosities of the reservoirs ranged from 17 to $25 \%$. The No. 7 and No. 6 blocks are located in Kelamayi oilfield of Xinjiang. The two oilfields are located in the Zhungeer Basin of northwestern China. The No. 7 block has been water-flooded for over $40 \mathrm{yr}$ and the No. 6 block for over $30 \mathrm{yr}$. The depths of the two blocks horizons ranged from $480 \mathrm{~m}$ to $1088 \mathrm{~m}$, with a typical low temperature of $21 \sim 32{ }^{\circ} \mathrm{C}$. The temperatures and the mineralization of the six sampled petroleum reservoirs range from 21 to $63{ }^{\circ} \mathrm{C}$ and 1301 to $11196 \mathrm{mg} \mathrm{l}^{-1}$, respectively, and the $\mathrm{pH}$ of these production waters were neutral or slightly alkaline. The characterization of the petroleum reservoirs water sampled are listed in Table 1. In order to characterize the microbial community from the different temperature petroleum reservoir, these samples were grouped into two classes: high-temperature $\left(45 \sim 63^{\circ} \mathrm{C}\right)$ and low-temperature $\left(21 \sim 37^{\circ} \mathrm{C}\right)$.

Ten liters of production water at wellhead were taken from each of the six production oil wells from six petroleum reservoirs. Samples were collected into sterile bottles to full capacity after discarding the initial oil/water mixture. The bottles were tightly sealed to avoid oxygen intrusion and immediately transported to the laboratory and filtered directly to minimize the chance of community changes. During filtration procedures, the residual oil was removed by heating the sample to $50^{\circ} \mathrm{C}$ for $15 \mathrm{~min}$ and by phase separation in 21 sterilized separatory funnels. The water samples were filtered through $0.22 \mu \mathrm{m}$ polycarbonate membranes $(25 \mathrm{~mm}$ diameter; Millipore, Bedford, USA). The polycarbonate membranes containing the cells were placed in a sterile centrifuge tube containing sterile silica beads for beating to break the cells. Genomic DNA was extracted by a method developed previously in this laboratory ( $\mathrm{Li}$ et al., 2007b).

\subsection{S rRNA gene amplification and cloning}

16S rRNA genes were amplified by PCR using the primers B27F [5'-AGAGTTTGATCCTGGCTCAG-3'] and B1492R [5'-TACGGYTACCTTGTTACGACTT-3'] (Nazina et al., 2006) for bacteria, and the primers A21F [5'TTCCGGTTGATCCYGCCGGA-3'] (De Long, 1992) and A1041R [5'-GGCCATGCACCWCCTCTC-3'] (Kolganova et al., 2002) for archaea. The final $50 \mu \mathrm{l}$ reaction mixture volume contained $2 \mu \mathrm{l}$ of template DNA, $0.5 \mu \mathrm{M}$ of each primer, $25 \mu \mathrm{l}$ of $2 \times$ Mastermix (Promega, USA), $21 \mu \mathrm{l}$ of nucleasefree water. Polymerase chain reaction cycles were performed on a Peltier thermal cycler (Bio-Rad, USA) as follows: after 5 min of initial denaturation at $95^{\circ} \mathrm{C}$, nucleic acids were amplified for 30 cycles $\left(45 \mathrm{~s}\right.$ of denaturation at $95^{\circ} \mathrm{C}, 45 \mathrm{~s}$ of 
Table 1. Characterization of the water samples collected from different petroleum reservoirs. $(\mathrm{Nd}=$ not detected.)

\begin{tabular}{|c|c|c|c|c|c|c|}
\hline & S1 Z3-26 & S2 B18-43 & S3 B51-45 & S4 M17-10 & S5 7222 & S6 6190 \\
\hline Depth (m) & $\sim 1300$ & $\sim 1490$ & $\sim 1101$ & $\sim 802$ & $\sim 1088$ & $\sim 480$ \\
\hline Temp $\left({ }^{\circ} \mathrm{C}\right)$ & 63 & 58 & 45 & 37 & 32 & 21 \\
\hline $\mathrm{pH}$ & 7.1 & 7.2 & 7.2 & 7.2 & 7.1 & 7.0 \\
\hline Effective thickness (m) & 4.2 & 5.0 & 5.2 & 14.4 & 15.7 & 18.4 \\
\hline Effective porosity (\%) & 30 & 17.3 & 22.2 & 24.7 & 17.4 & 20.5 \\
\hline Average permeability $\left(\times 10^{-3} \mu \mathrm{m}^{2}\right)$ & 800 & 691 & 12.6 & 675.3 & 274 & 466 \\
\hline Oil viscosity (mPa.s) & 1720 & 13.7 & 402 & 179.1 & 44.8 & 417 \\
\hline Water flooding operation (years) & 22 & 10 & 4 & 22 & 46 & 38 \\
\hline Mineralization $\left(\mathrm{mg} \mathrm{l}^{-1}\right)$ & 8425 & 2891 & 4091 & 1121 & 15728 & 4212 \\
\hline $\mathrm{Cl}^{-}\left(\mathrm{mg} \mathrm{l}^{-1}\right)$ & 3850 & 361 & 819 & 447 & 2000 & 3864 \\
\hline $\mathrm{SO}_{4}^{2-}\left(\mathrm{mg} \mathrm{l}^{-1}\right)$ & 2244 & 12.1 & 32.4 & 6.8 & 7.7 & 124.8 \\
\hline $\mathrm{PO}_{4}^{3-}\left(\mathrm{mg} \mathrm{l}^{-1}\right)$ & 0.1 & $\mathrm{Nd}$ & $\mathrm{Nd}$ & 0.08 & $\mathrm{Nd}$ & $\mathrm{Nd}$ \\
\hline $\mathrm{NO}_{3}^{-}\left(\mathrm{mg} \mathrm{l}^{-1}\right)$ & $\mathrm{Nd}$ & $\mathrm{Nd}$ & $\mathrm{Nd}$ & $\mathrm{Nd}$ & 1.4 & 34.1 \\
\hline $\mathrm{Na}^{+}\left(\mathrm{mgl}^{-1}\right)$ & 3313 & 1629 & 1064 & 618.3 & 5399 & 4196 \\
\hline $\mathrm{K}^{+}\left(\mathrm{mg} \mathrm{l}^{-1}\right)$ & 94.2 & 28.1 & 22.3 & 4.2 & 45.6 & 35.1 \\
\hline $\mathrm{Ca}^{2+}\left(\mathrm{mg} \mathrm{l}^{-1}\right)$ & 195.6 & 3.6 & 53.0 & 19.2 & 128.2 & 103.3 \\
\hline $\mathrm{Mg}^{2+}\left(\mathrm{mg} \mathrm{l}^{-1}\right)$ & 46.1 & 1.4 & 17.6 & 0.15 & 64.0 & 44.7 \\
\hline $\mathrm{Mn}^{2+}\left(\mathrm{mg} \mathrm{l}^{-1}\right)$ & 0.3 & $\mathrm{Nd}$ & 0.1 & $\mathrm{Nd}$ & 0.4 & 0.3 \\
\hline Acetate $\left(\mathrm{mg} \mathrm{l}^{-1}\right)$ & 32 & 856 & 57.9 & 5.3 & 6.97 & 344 \\
\hline Propionate $\left(\mathrm{mg} \mathrm{l}^{-1}\right)$ & 1.2 & 8.0 & $\mathrm{Nd}$ & $\mathrm{Nd}$ & $\mathrm{Nd}$ & $\mathrm{Nd}$ \\
\hline Isobutyrate $\left(\mathrm{mg} \mathrm{l}^{-1}\right)$ & $\mathrm{Nd}$ & 13.8 & $\mathrm{Nd}$ & 9.8 & $\mathrm{Nd}$ & 32.7 \\
\hline Butyrate $\left(\mathrm{mg} \mathrm{l}^{-1}\right)$ & 0.2 & 2.3 & 0.5 & 2.3 & $\mathrm{Nd}$ & $\mathrm{Nd}$ \\
\hline
\end{tabular}

annealing at $50^{\circ} \mathrm{C}$ and $1 \mathrm{~min}$ of elongation at $72^{\circ} \mathrm{C}$ ), followed by a final extension step at $72^{\circ} \mathrm{C}$ for $20 \mathrm{~min}$. PCR products were separated on $0.8 \%(w / v)$ agarose gel and stained with ethidium bromide. The amplicons were cloned into a pMD19-T Simple vector (Takara, Japan) according to the manufacturer's instructions.

\subsection{Sequencing and phylogenetic analysis}

Inserts of selected clones were amplified by PCR with forward M13F (5'-GTTTTCC CAGTCACGA-3') and the reverse M13R (5'-CAGGAAACAGCTATGAC-3') plasmid specific primer set. The sequencing was performed on an ABI 377 sequencer (Dye Terminator Cycle Sequencing Ready Reaction FS Kit; PE Applied Biosystems) using M13 universal sequencing primers. Obtained DNA sequences were checked for vectors by VecScreen Widget 1.0 software before further analysis. Sequence data were aligned using the NAST alignment algorithm (De Santis et al., 2006a) on the Greengenes website (http://greengenes.lbl.gov), with clones having similarities of $98 \%$ or above grouped into operational taxonomic units (OTUs). The clones were homologysearched using Ribosomal Database Project II (Wang et al., 2007). The nearest relatives of each OTU were identified using the BLASTN network service (Altschul et al., 1997). Chimeras were detected using Bellerophon, version 3 (Huber et al., 2004; De Santis et al., 2006b) and removed from further examination. Phylogenetic trees were constructed based on the neighbor-joining algorithm (Saitou and Nei, 1987) using the MEGA5 software (Tamura et al., 2011). Bootstrap analysis with 1000 replicates was applied to assign confidence levels to the nodes in the trees.

\subsection{Statistical analysis}

The coverage of each clone library was calculated by the equation $\mathrm{C}=\left[1-\left(n_{1} / \mathrm{N}\right)\right] \times 100$, where $n_{1}$ is the number of OTUs represented by only one clone and $\mathrm{N}$ is the total number of clones examined (Good, 1953). To examine the temperature distribution of microbial community in production water of petroleum reservoir, 16S rRNA gene sequences were analyzed with the online software UniFrac (http://bmf2.colorado.edu/unifrac/) using the principal coordinates analysis (PCoA) as suggested previously (Lozupone and Knight, 2005). Correlations between the microbial communities and environmental factors were determined by the canonical correspondence analysis (CCA) using the software CANOCO (version 4.5, Microcomputer Power, Ithaca, NY, USA) (ter Braak and Šmilauer, 2002).

\subsection{Nucleotide sequence accession numbers}

Partial 16S rRNA gene sequences for Bacteria and Archaea obtained in this study were deposited in GenBank database under accession numbers JQ433723-JQ433816 and JF754550-JF754565. 


\section{Results}

\subsection{Diversity of microbial community in water-flooding petroleum reservoirs}

Six production water samples from six water-flooding petroleum reservoirs with different temperatures were analyzed by PCR amplification with bacterial and archaeal specific primer sets. For the members in the domain bacteria, 93, 226, 254, 80, 185 and 142 clones were randomly selected from the libraries of production water samples S1, S2, S3, S4, S5 and S6, respectively. Of the total sequences screened by MOTHUR software version 1.6, 5, 16, 10, 13, 30 and 31 operational taxonomy units (OTUs) were obtained from S1, S2, S3, S4, S5 and S6, respectively and classified into thirteen different phylogenetic groups (phylum level) (Figs. 1, 2 and 3). The coverage of the clone library was $100 \%$ for S1, S2, S3 and S5, $96 \%$ for S4 and 99\% for S6 from rarefaction analysis .

For the members in the domain archaea, 125, 56, 79, 60, 24 and 33 clones were randomly selected from the libraries of production water samples S1, S2, S3, S4, S5 and S6, respectively. Of the total sequences screened by MOTHUR software version 1.6, 5, 1, 4, 2, 2 and 2 OTUs were obtained from S1, S2, S3, S4, S5 and S6, respectively and classified into eleven different phylogenetic groups (genus level) (Fig. 4). The coverage of the clone library was all $100 \%$ except $98 \%$ for $\mathrm{S} 1$ from rarefaction analysis.

Bacterial and archaeal DNA sequences based on the percentage representation of major phylum or genus in clone libraries from the six different temperature reservoirs are shown in Fig. 5. The bacterial sequences were clustered within thirteen phyla: Proteobacteria $(\alpha-, \beta-, \gamma-, \delta-, \varepsilon-)$, Firmicutes, Bacteroidetes, Actinobacteria, Chloroflexi, Thermotogae, Thermodesulfobacteria, Deinococcus-Thermus and TM7. Compared with low-temperature reservoir, bacterial sequences affiliated with the phylum Firmicutes account for the highest percentage in S2 $(65.9 \%)$ and S3 $(29.9 \%)$ from high-temperature petroleum reservoir. In contrast, Proteobacteria $(\alpha-, \beta-, \gamma-, \delta-, \varepsilon-)$ account for the highest percentage in the S4, S5 and S6 from low-temperature petroleum reservoirs. $\alpha$-Proteobacteria increased with the decrease of petroleum reservoir temperature, but the percentage of $\beta$-Proteobacteria decreased with the reduction of petroleum reservoir temperature. $\gamma$-Proteobacteria shared similar high percentage $(30 \sim 40 \%)$ in the S4, S5 and S6 as well as in S2 (31.5\%). However, it is surprising that all the bacterial sequences found in S1 affiliated with $\gamma$ Proteobacteria. $\gamma$-Proteobacteria was also detected in S3 and S6 with $7.1 \%$ and $0.7 \%$, respectively. $\varepsilon$-Proteobacteria were encountered in S2 and S5 accounting for $2.7 \%$ and $5.1 \%$, respectively. Bacteroidetes was another frequently encountered phylum in low-temperature petroleum reservoir of S5 and S6 for $9.0 \%$ and $17.6 \%$, respectively. Thermotogae with higher percentage accounted for $19.5 \%$ in a high-temperature petroleum reservoir. The remaining bacterial phyla account for relative low abundance in the six petroleum reservoirs.

The archaeal sequences were clustered within eleven phylogenetic groups (genus level): Methanocella, Methanosaeta, Methanomethylovorans, Methanolinea, Methanocalculus, Methanoculleus, Methanothermobacter, Methanobacterium, Thermococcus, Halogeometricum and Thermogymnomonas. In the high-temperature oil reservoirs, most of the genera belong to the thermophilic archaea. The sequences affiliated with the genus Thermococcus and Methanothermobacter account for a high percentage, $88.8 \%$ of total archaeal clones with the genus Thermococcus in S1 and all the archaeal clones affiliated with the genus Methanothermobacter in S2. The sequences related to the genus Methanomethylovorans and accounting for $54.4 \%$ was only found in S3. The sequences affiliated with the genus Methanolinea were detected in S4 with a high percentage $(70 \%)$. The sequences affiliated with the genus Methanobacterium were the most abundant in low-temperature petroleum reservoirs, accounting for $79.2 \%$ in S5 and $66.7 \%$ in S6.

\subsection{Microbial community classification of water-flooding petroleum reservoirs}

PCoA of bacterial and archaeal community structures carried out by Unifrac based on the phylogenetic tree of $16 \mathrm{~S}$ rRNA gene sequences in the six investigated petroleum reservoirs indicates that bacteria and archaea display high niche specificity (Fig. 6). S5 and S6 were collected from lowtemperature petroleum reservoirs grouped together, sharing similar bacterial and archaeal community structures. Although S1 and S2 represented high-temperature petroleum reservoirs, neither bacteria nor archaea community structures got grouped together because of a great difference in mineralization and the concentration of $\mathrm{Cl}^{-}$. In addition, $\mathrm{S} 2$ and $\mathrm{S} 3$ got grouped together, sharing similar bacterial community structures in PCoA of bacterial classification, while S3 and S4 got grouped together, sharing similar archaeal community structures in PCoA of archaeal classification.

\subsection{Correlations of microbial communities with environmental factors}

To find out the relationships between the distribution of microbial communities and the environmental variables of the petroleum reservoirs, canonical correspondence analysis was conducted based on bacterial and archaeal $16 \mathrm{~S}$ rRNA gene sequences and the major physiochemical parameters of the petroleum reservoirs (Table 1). The first two axes of the CCA analysis explained $69.9 \%$ and $55.3 \%$ of the total variance for the bacterial and archaeal communities, respectively (Fig. 7). The physiochemical parameters of petroleum reservoirs were divided to three groups to better analyze the relationships. In the first group, the differences 


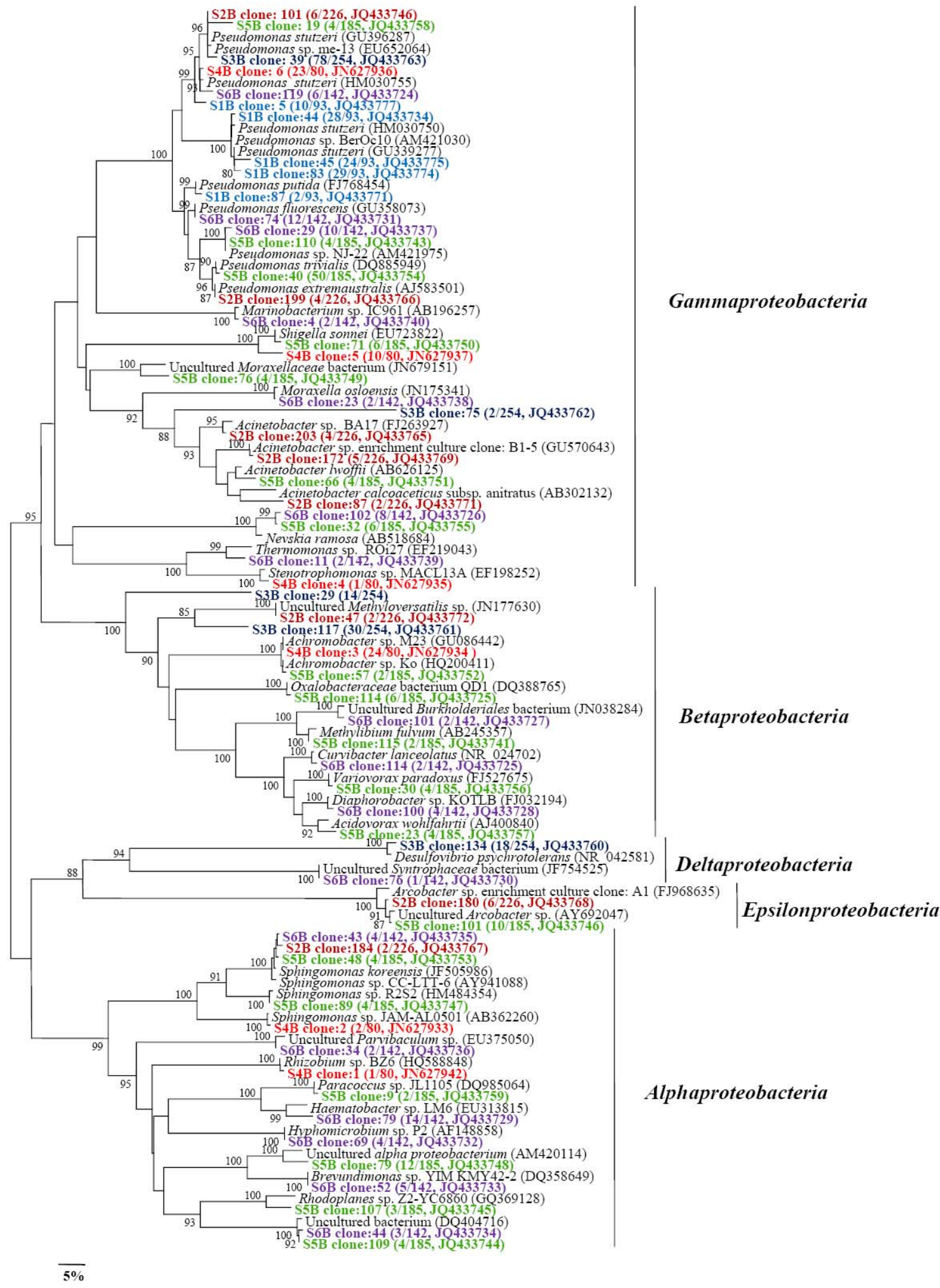

Fig. 1. Phylogenetic tree of the Alphaproteobacteria, Betaproteobacteria, Gammaproteobacteria, Deltaproteobacteria and Epsilonproteobacteria 16S rRNA gene phylotypes retrieved from six different petroleum reservoirs (shown in bold) and closely related sequences from GenBank database. Alignments to related sequences (shown with accession number) were performed with MEGA 5 software. The topology of the tree was obtained with the neighbor-joining method. Bootstrap values $(n=1000$ replicates $)$ of $\geq 75 \%$ are reported. Scale bar represents nucleotide changes per site. Sampling locations are as named in Table 1. 


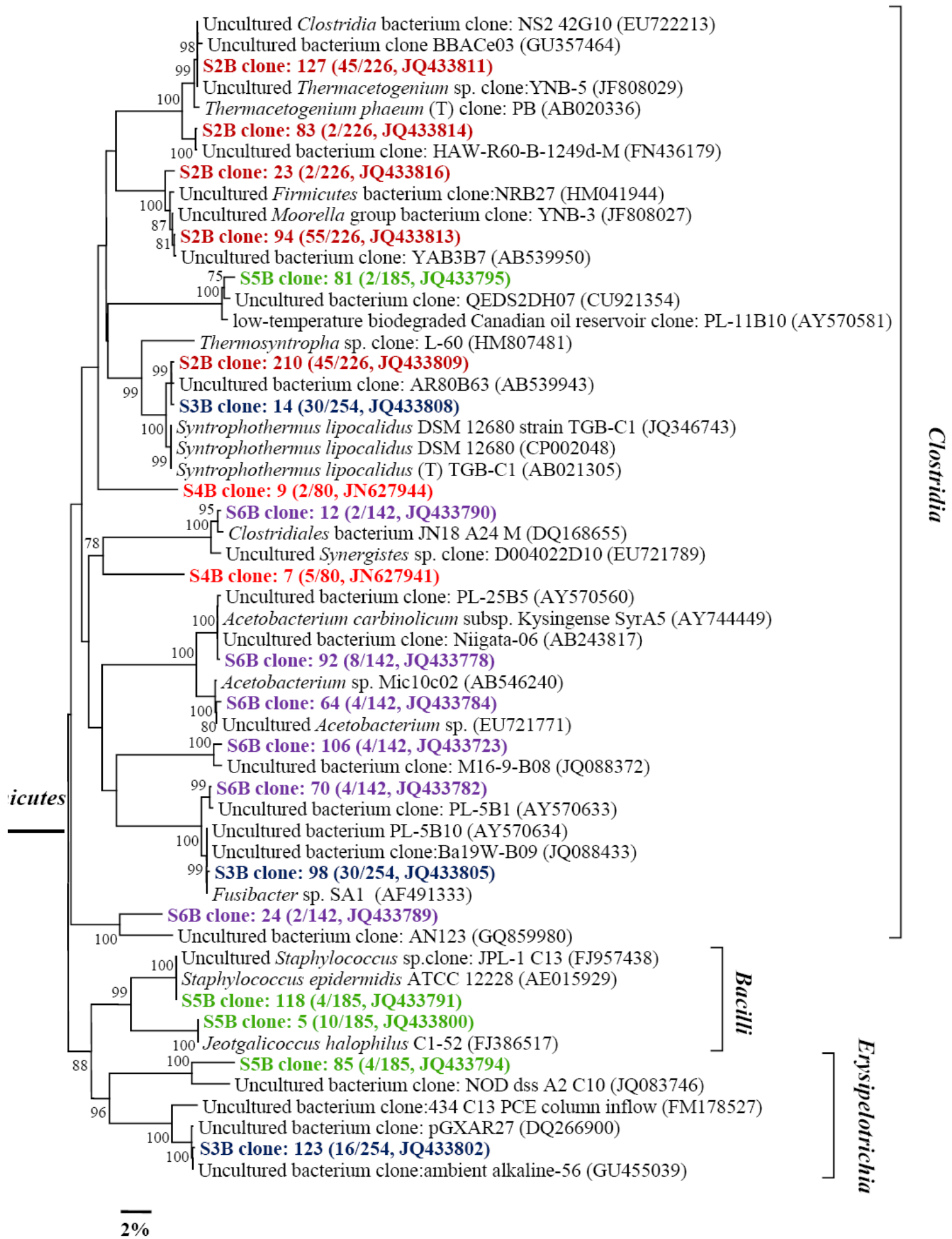

Fig. 2. Phylogenetic tree of the Firmicutes $16 \mathrm{~S}$ rRNA gene phylotypes retrieved from six different petroleum reservoirs (shown in bold) and closely related sequences from GenBank database. Alignments to related sequences (shown with accession number) were performed with MEGA 5 software. The topology of the tree was obtained with the neighbor-joining method. Bootstrap values $(n=1000$ replicates) of $\geq$ $75 \%$ are reported. Scale bar represents nucleotide changes per site. Sampling locations are as named in Table 1. 


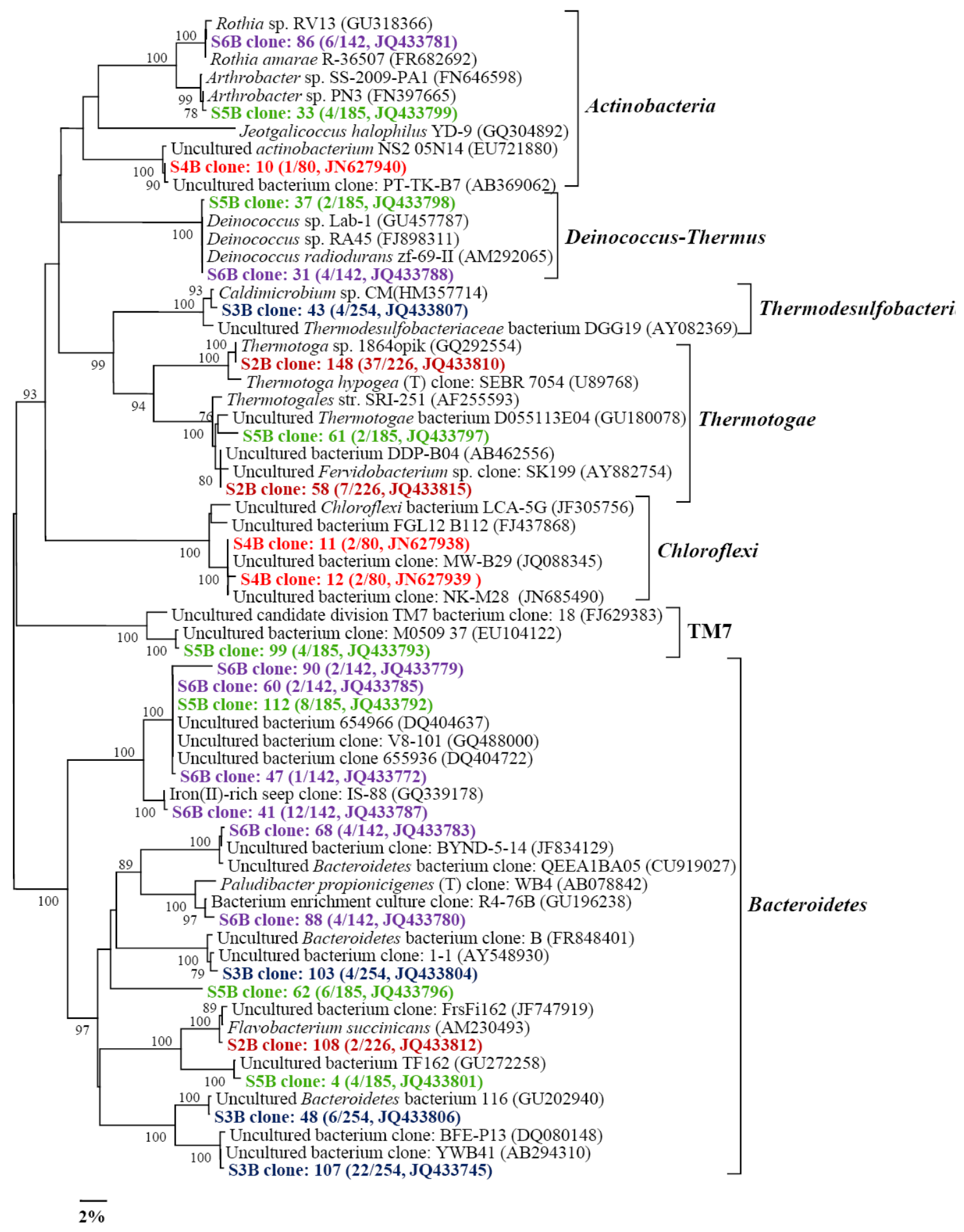

Fig. 3. Phylogenetic tree of the Actinobacteria, Thermodesulfobacteria, Thermotogae, Deinococcus-Thermus, Chloroflexi, Bacteroidetes and TM7 16S rRNA gene phylotypes retrieved from six different petroleum reservoirs (shown in bold) and closely related sequences from GenBank database. Alignments to related sequences (shown with accession number) were performed with MEGA 5 software. The topology of the tree was obtained with the neighbor-joining method. Bootstrap values ( $n=1000$ replicates) of $\geq 75 \%$ are reported. Scale bar represents nucleotide changes per site. Sampling locations are as named in Table 1. 


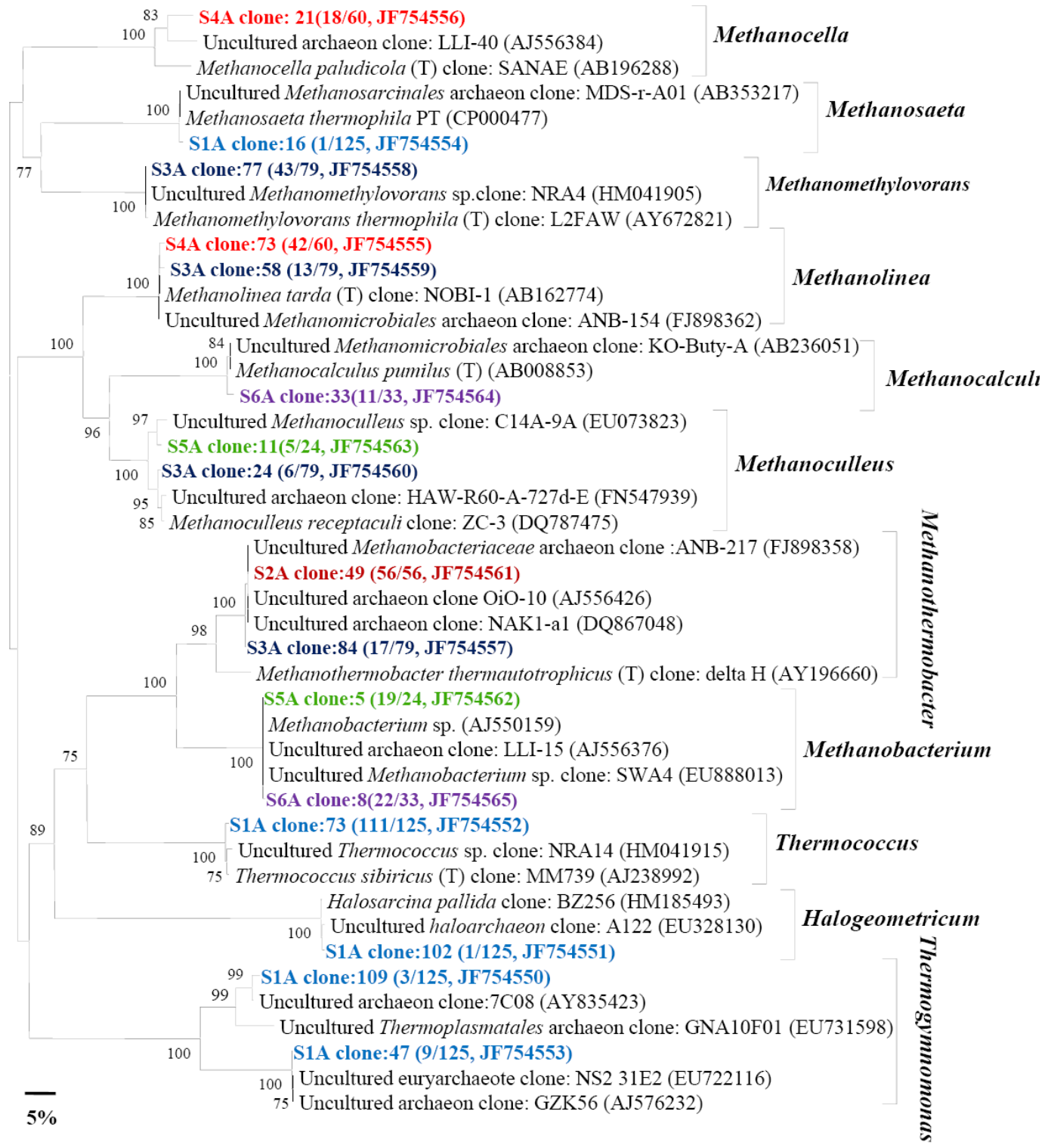

Fig. 4. Phylogenetic tree of the archaeal $16 \mathrm{~S}$ rRNA gene phylotypes retrieved from six different petroleum reservoirs (shown in bold) and closely related sequences from GenBank database. Alignments to related sequences (shown with accession number) were performed with MEGA 4 software. The topology of the tree was obtained with the neighbor-joining method. Bootstrap values $(n=1000$ replicates) of $\geq$ $75 \%$ are reported. Scale bar represents nucleotide changes per site. Sampling locations are as named in Table 1.

in the bacterial and archaeal community structures (Fig. 7A and a) were related to temperature, mineralization, average permeability, oil viscosity, effective porosity, effective thickness and water flooding operation years. The bacterial phylogenic group of Firmicutes and Thermotogae had positive correlation with the temperature, $\gamma$-Proteobacteria and Chloroflexi with the effective porosity and oil viscosity, others with the effective thickness and waterflooding operation years; Most of the archaeal phylogenetic groups (Methanocella, Methanosaeta, Methanomethylovorans, Methanolinea, Methanothermobacter, Thermococcus,
Halogeometricum and Thermogymnomonas) correlated positively with the temperature, others with the water-flooding operation years, mineralization and effective thickness. In the second group, the differences in the bacterial and archaeal community structure (Fig. 7B and b) were related to differences in the concentration of $\mathrm{Cl}^{-}, \mathrm{SO}_{4}^{2-}, \mathrm{PO}_{4}^{3-}, \mathrm{NO}_{3}^{-}$, $\mathrm{Na}^{+}, \mathrm{K}^{+}, \mathrm{Ca}^{2+}, \mathrm{Mg}^{2+}$, and $\mathrm{Mn}^{2+}$. The bacterial phylogenic group of Bacteroidetes, $\alpha$-Proteobacteria, Actinobacteria, and Deinococcus-Thermus showed positive correlation with the concentration of $\mathrm{NO}_{3}^{-}, \beta$-Proteobacteria with the concentration of $\mathrm{Cl}^{-}, \gamma$-Proteobacteria and Chloroflexi with the 
A

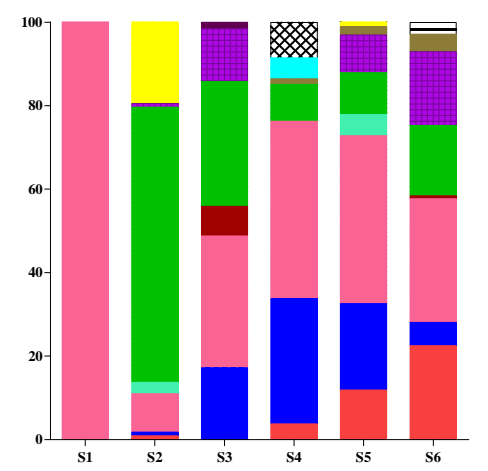

B

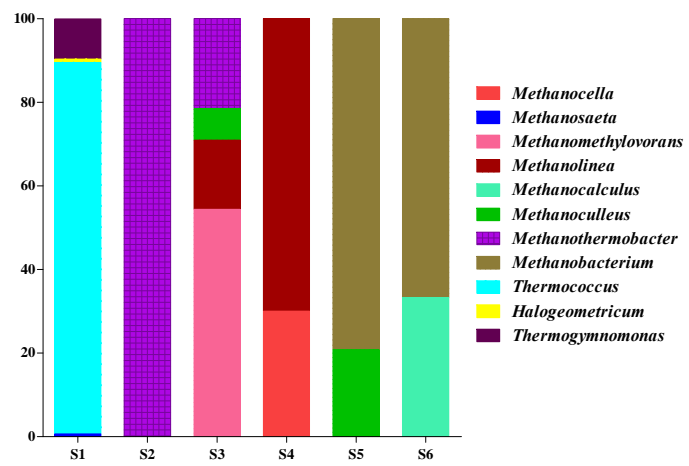

Fig. 5. Relative proportion of bacterial (A) and archaeal (B) taxa from 16S rRNA gene sequence clone libraries constructed from DNA extracted from production waters collected from oil reservoirs with temperatures $63,58,45,37,32$ and $21^{\circ} \mathrm{C}$. Sampling locations are as named in Table 1.

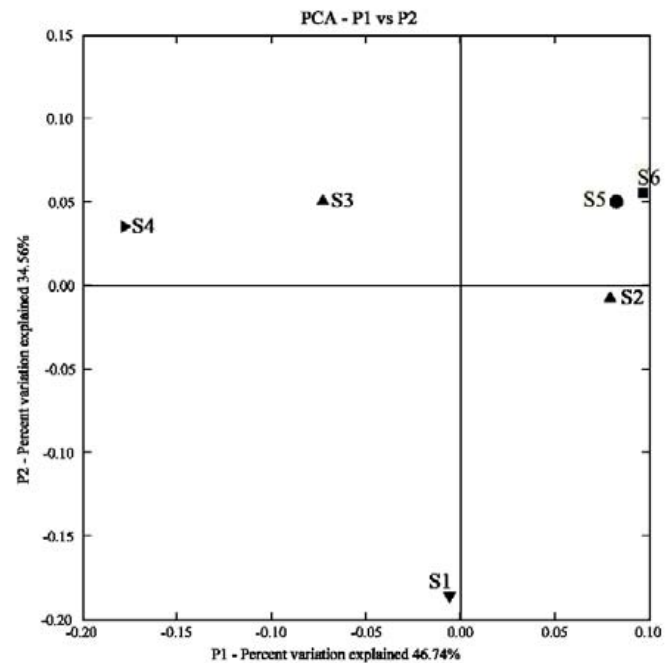

A

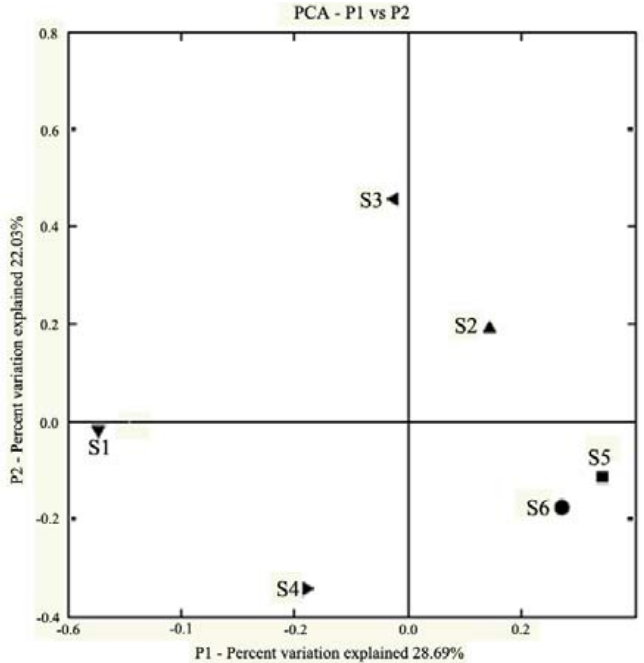

B

Fig. 6. PCoA ordination diagrams of the bacterial (A) and archaeal (B) assemblages calculated with 16S rRNA gene sequences from production water of petroleum reservoirs. Shown are the plots of the first two principal coordinate axes (P1 and P2) for PCoA and the distributions of the bacterial and archaeal assemblages (designated with the sampling wells) in response to these axes.

concentration of $\mathrm{SO}_{4}^{2-}$ and $\mathrm{PO}_{4}^{3-}$; The archaeal phylogenetic groups of Methanosaeta, Thermococcus, Halogeometricum and Thermogymnomonas correlated positively with the concentration of $\mathrm{SO}_{4}^{2-}$, Methanocalculus, Methanobacterium and Methanoculleus with the concentration of $\mathrm{NO}_{3}^{-}$. In the third group, the differences in the bacterial and archaeal community structure (Fig. 7C and c) were related to differences in the concentration of volatile fatty acid including acetate, propionate, isobutyrate and butyrate. The bacterial phylogenetic groups of Thermotogae showed positive correlation with the concentration of propionate, Firmicutes with the concentration of acetate, except for $\gamma$-Proteobacteria,
Chloroflexi and others that had correlation with the concentration of isobutyrate; the archaeal phylogenetic groups of Methanomethylovorans, Methanothermobacter, Methanolinea and Methanocella had positive correlation with the concentration of butyrate, Methanoculleus with the concentration of isobutyrate.

\section{Discussion}

It has been widely accepted that the combination of temperature, salinity and pressure in subsurface petroleum reservoirs drastically reduces microbial populations and metabolic 
A

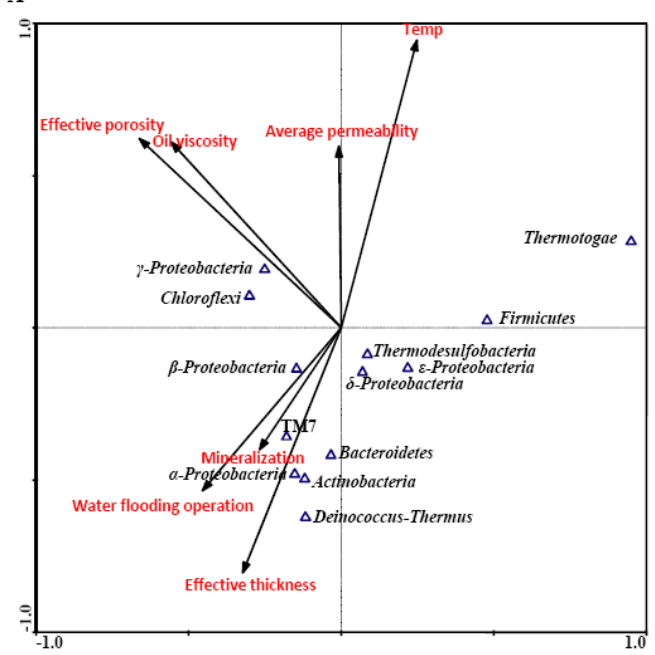

B
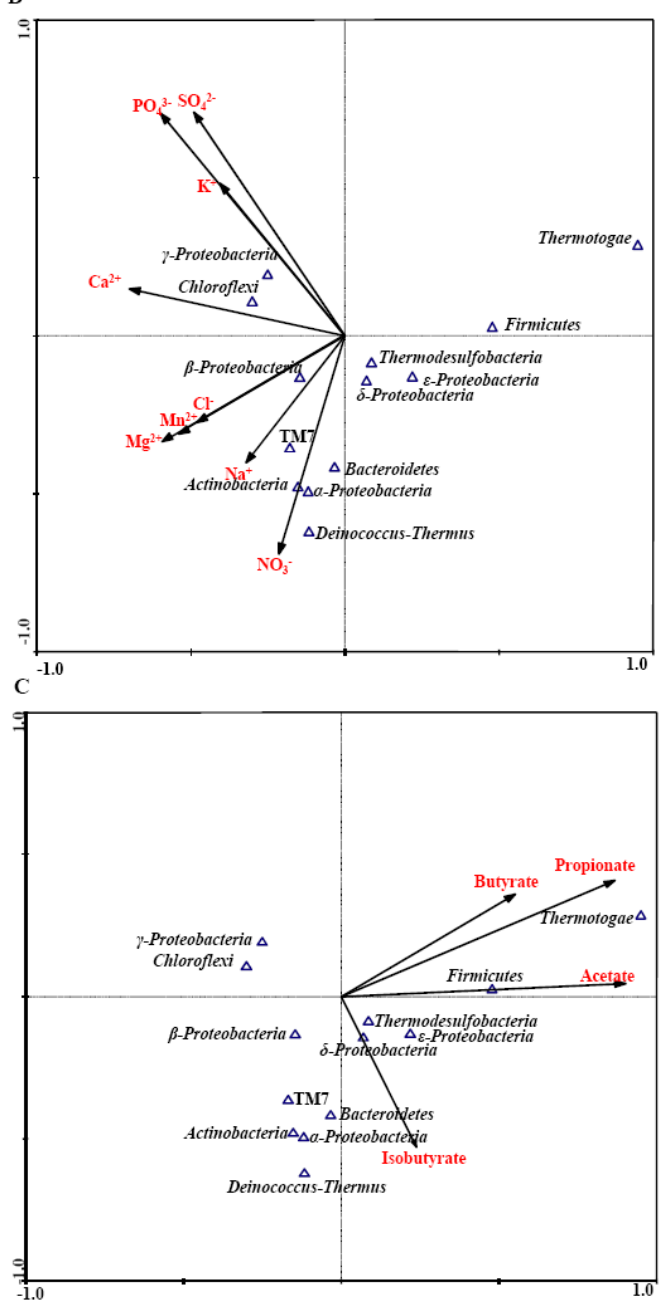

a
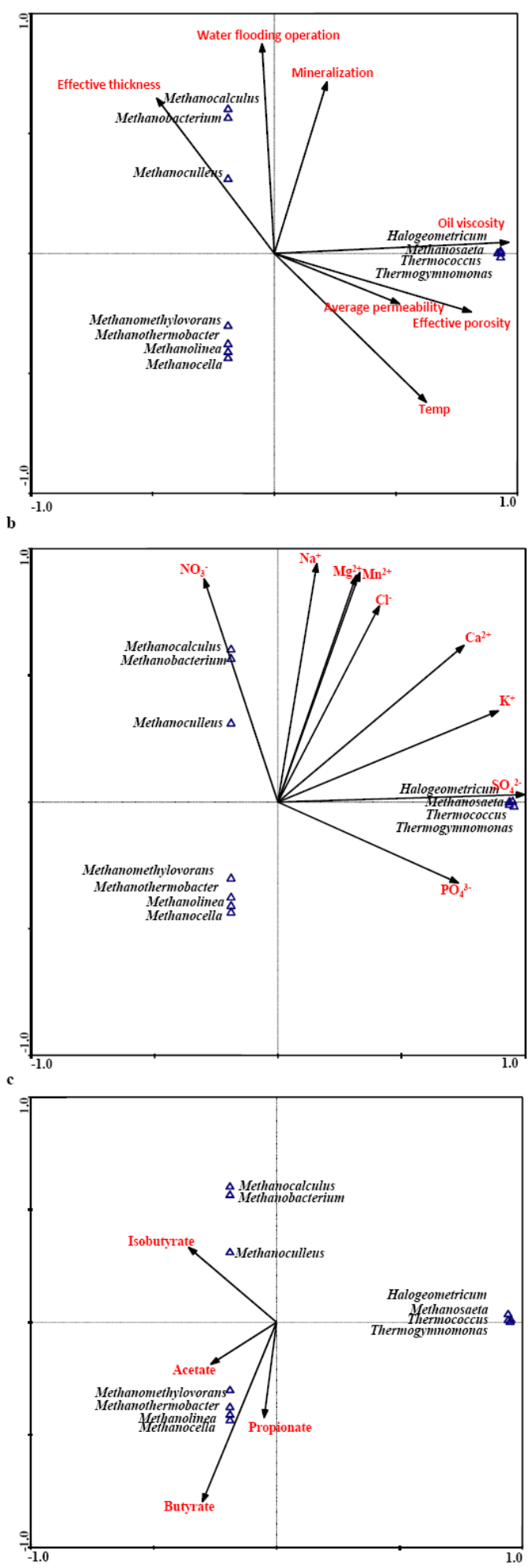

Fig. 7. CCA ordination plots for the first two dimensions to show the relationship between the bacterial and archaeal diversity with environmental factors analyzed using a 16S rRNA gene sequence in the production water of petroleum reservoirs. Correlations between environmental variables and CCA axes are represented by the length and angle of arrows (environmental factor vectors), designated with the bacterial group was showed in (A), (B) and (C) and designated with the archaeal group was showed in (a), (b) and (c). 
activity. The microbial population differs from one oil reservoir to another because of variations in their physicochemical, and geochemical entities. Physiologically diverse microbial assemblage of mesophilic to thermophilic and halophilic to hyperhalophilic microbes are distributed in such ecosystems. Owing to having a high correlation between the depth and the temperature of petroleum reservoir, the best dependable research may be to sample a single oil reservoir with different depths to survey the effect of temperature on the microbial community. Even if this method can effectively avoid the interference of other environment factors on microbial communities except for temperature, nevertheless, the sample collection will undoubtedly face enormous challenges. In general, the oil layer is quite centralized in thickness, the thickness of oil layer is no more than $200 \mathrm{~m}$ and the difference in temperature is less than $5^{\circ}$. Therefore, it is very difficult to sample the different temperature oil production water from a single oil reservoir.

In order to compare the results of this study with other related researches, the microbial community based on 16S rRNA gene sequencing surveys conducted on different temperature petroleum reservoirs from related references and this study were listed in Table 2. Obviously, in this study most of the thermophilic microorganisms including Thermococcus, Thermogymnomonas, Methanothermobacter, Firmicutes and Thermotogae were dominant, which are in line with other related high-temperature oil reservoir research, such as the survey of the continental Huabei oilfield in China, the Troll oil formation in the North Sea and an offshore oilfield in Qinghuang, China. In the low petroleum reservoir, the bacterial sequences affiliated with the phylum Proteobacteria were dominant; the same phenomenon has also been observed in other low-temperature reservoir studies in Schrader Bluff Formation of Alaska and Pelican lake oil field.

The bacterial sequences with close affiliation to members of the Firmicutes had the greatest proportion in high-temperature reservoirs. Dominant groups within the Firmicutes were those of the family Peptococcaceae, Thermoanaerobacteraceae, Syntrophomonadaceae, Lachnospiraceae, Erysipelotrichaceae and Incertae Sedis XII. Members of these groups are thermophilic and obligate anaerobic microorganisms. The sequence type (S2 B clone: 94) retrieved from oil reservoirs with temperature of $58^{\circ} \mathrm{C}$ in this study is most closely related to Pelotomaculum thermopropionicum, a member of Clostridialesand a well described thermophilic propionate-oxidizing anaerobic bacterium isolated from an anaerobic sludge blanket reactor in Niigata, Japan (Imachi et al., 2002). Such a microorganism was once postulated to be associated with hydrocarbon-degradation (Abu Laban et al., 2009; Gieg et al., 2008). The sequence type (S2 B clone: 127) is most closely related to Thermacetogenium phaeum, is a strictly anaerobic, thermophilic, syntrophic acetate-oxidizing bacterium, which can oxidize acetate in co-culture with a thermophilic hydrogenotrophic methanogen (Hattori et al., 2000). The sequence types (S2 B clone: 210 and S3 B clone: 14) are most closely related to Syntrophothermus lipocalidus, a novel thermophilic, syntrophic isobutyrate-oxidizing bacterium (Sekiguchi et al., 2000). According to the physicochemical data from production water samples and CCA analysis, the bacterial group Firmicutes showed higher values for acetate, propionate, isobutyrate and butyrate (Fig. 7C), suggesting that VFA (volatile fatty acid) components within the production water serve as their major carbon sources, and demonstrated a higher support between the phylogenetic data and the physicochemical measurements. Other sequence type within the phylum Firmicutes also had a greater proportion in high-temperature reservoirs, such as sequence type (S3B clone: 98), most closely related to Fusibacter spp., an anaerobic, thiosulfate-reducing bacterium isolated from an oil-producing well (Ravot et al., 1999). It is not a typical thermophilic microorganism with optimal growth temperature at $37^{\circ} \mathrm{C}$, and such types of sequences were also found in low-temperature petroleum reservoirs, represented as (S6 B clone: 70) with petroleum temperature at $20^{\circ} \mathrm{C}$. CCA analysis showed that the phylum Thermotogae is another bacterial group correlated positively with the temperature. The sequence types (S2 B clone: 210 and S3 B clone: 14) are most closely related to Thermotoga hypogeal, a xylanolytic, thermophilic, strictly anaerobic bacterium isolated from an oil-producing well (Fardeau et al., 1997). Many thermophilic bacteria with optimum growth temperatures from 45 to $80^{\circ} \mathrm{C}$ have been isolated from oil fields (Beeder et al., 1995; Cayll et al., 1995; Jeanthon et al., 1995; Ravot et al., 1995; Rees et al., 1995; Fardeau et al., 1996; Nilsen et al., 1996; Fardeau et al., 1997). In this study, although S1, S2 and S3 represent thermophilic temperature, not all of the bacterial sequences belonged to thermophilic microorganisms, especially bacterial sequences affiliated with Pseudomonas spp. within the phylum $\gamma$-Proteobacteria in S1 with temperature at $63^{\circ} \mathrm{C}$. It may be that microbial populations are greatly reduced in petroleum reservoirs with the combination of high temperature, high mineralization and high concentration of $\mathrm{SO}_{4}^{2-}$.

In addition, CCA analysis indicated that temperature exhibited the greatest influence on the archaeal community. The archaea identified from the petroleum reservoirs samples are overwhelmingly methanogens including methyltrophic (Methanomethylovorans), acetoclastic (Methanosaeta) and $\mathrm{CO}_{2}$-reducing methanogens (Methanothermobacter, Methanoculleus, Methanobacteria, Methanocalculus Methanocella and Methanolinea), possibly being mesophilic or thermophilic. In contrast, in sample S1 with the highest temperature $\left(63^{\circ} \mathrm{C}\right)$, besides Methanosaeta $(0.8 \%$ of total clones), the majority of the clones were phylogenetically related to the genus Thermococcus (88.8\% of total clones) and to the species T. sibiricus (99\% sequence similarity) (Fig. 4). Clones pertaining to Thermogymnomonas (9.6\% of total clones) and Halogeotricum (0.8\% of total clones) were also detected, but to a lesser extent in sample S1. Most 
Table 2. 16S rRNA gene sequencing surveys conducted in different temperature petroleum reservoirs.

\begin{tabular}{|c|c|c|c|c|c|c|}
\hline \multicolumn{3}{|c|}{ This article } & \multicolumn{4}{|c|}{ Other research } \\
\hline Sample & $\begin{array}{l}\text { Temp } \\
\left({ }^{\circ} \mathrm{C}\right)\end{array}$ & Lineages detected & $\begin{array}{l}\text { Oil reservoir } \\
\text { site }\end{array}$ & $\begin{array}{l}\text { Temp } \\
\left({ }^{\circ} \mathrm{C}\right)\end{array}$ & Lineages detected & Reference \\
\hline $\mathrm{S} 1$ & 63 & $\begin{array}{l}\gamma \text {-Proteobacteria, } \\
\text { Thermococcus, } \\
\text { Thermogymnomonas, } \\
\text { Halogeotricum, } \\
\text { Methanosaeta }\end{array}$ & $\begin{array}{l}\text { Hubei oil } \\
\text { field, China }\end{array}$ & 75 & $\begin{array}{l}\alpha, \beta, \gamma, \varepsilon \text {-Proteobacteria, } \\
\text { Firmicutes, Actinobacteria, } \\
\text { Thermotogales, Nitrospira, } \\
\text { Methanobacteriales, } \\
\text { Methanococcales, Methanomicro- } \\
\text { biales, Methanosarcinales }\end{array}$ & $\begin{array}{l}\text { Li et al. } \\
(2006,2007)\end{array}$ \\
\hline $\mathrm{S} 2$ & 58 & $\begin{array}{l}\text { Firmicutes, } \\
\text { Thermotogae, } \alpha, \beta, \gamma, \\
\text { E-Proteobacteria, } \\
\text { Bacteroidetes } \\
\text { Methanothermobacter }\end{array}$ & $\begin{array}{l}\text { Troll oil for- } \\
\text { mation, } \\
\text { North sea }\end{array}$ & 70 & $\begin{array}{l}\text { Firmicutes, } \gamma, \delta \text {-Proteobacteria, } \\
\text { Thermotogales, Spirochetes, } \\
\text { Bacteroidetes, Methanococcus, } \\
\text { Methanolobus, } \\
\text { Thermococcus }\end{array}$ & $\begin{array}{l}\text { Dahle et al. } \\
\text { (2008) }\end{array}$ \\
\hline S3 & 45 & $\begin{array}{l}\text { Firmicutes, } \beta, \gamma, \delta \text { - } \\
\text { Proteobacteria, } \\
\text { Bacteroidetes, Ther- } \\
\text { modesulfobacteria, } \\
\text { Methanomethylovorans, } \\
\text { Methanothermobacter, } \\
\text { Methanolinea, } \\
\text { Methanoculleus }\end{array}$ & $\begin{array}{l}\text { Multiple oil } \\
\text { fields, } \\
\text { California }\end{array}$ & $\begin{array}{l}70 \\
\sim \\
75\end{array}$ & $\begin{array}{l}\alpha, \beta, \gamma, \delta \text {-Proteobacteria, } \\
\text { Bacteroidetes, Firmicutes, } \\
\text { Methanomicrobiales, } \\
\text { Methanosarcinales, } \\
\text { Thermococcales }\end{array}$ & $\begin{array}{l}\text { Orphan et al. } \\
(2000)\end{array}$ \\
\hline $\mathrm{S} 4$ & 37 & $\begin{array}{l}\alpha, \beta, \gamma \text {-Proteobacteria, } \\
\text { Firmicutes, } \\
\text { Chloroflexi, } \\
\text { Actinobacteria, } \\
\text { Methanolinea, } \\
\text { Methanocella }\end{array}$ & $\begin{array}{l}\text { Qinghuang } \\
\text { offshore } \\
\text { oil field, } \\
\text { China }\end{array}$ & 65 & $\begin{array}{l}\text { Firmicutes, Nitrospira, Thermoto- } \\
\text { gae, } \alpha, \beta, \gamma, \varepsilon \text {-Proteobacteria, } \\
\text { Methanobacteriales, } \\
\text { Methanococcales, Crenarchaeota }\end{array}$ & $\begin{array}{l}\text { Li et al. } \\
\text { (2007) }\end{array}$ \\
\hline S5 & 32 & $\begin{array}{l}\alpha, \beta, \gamma, \\
\varepsilon \text {-Proteobacteria, } \\
\text { Firmicutes, } \\
\text { Bacteroidetes, } \\
\text { Actinobacteria } \\
\text { Methanobacterium, } \\
\text { Methanoculleus }\end{array}$ & $\begin{array}{l}\text { Schrader } \\
\text { Bluff } \\
\text { Formation } \\
\text { of Alaska }\end{array}$ & 27 & $\begin{array}{l}\text { Proteobacteria, Firmicutes, Syn- } \\
\text { trophs*, WS6, Spirochaetes, } \\
\text { Deferribacteres, Bacteroidetes, } \\
\text { Chloroflexi, Thermotogae, Acti- } \\
\text { nobacteria, OP11, OP9, } \\
\text { Thermodesulfobacteria, } \\
\text { Methanosaeta } \\
\text { Methanoplanus, Methanolobus, } \\
\text { Methanocalculus, Methanoculleus }\end{array}$ & $\begin{array}{l}\text { Pham et al. } \\
\text { (2009) }\end{array}$ \\
\hline S6 & 21 & $\begin{array}{l}\alpha, \beta, \gamma \text {-Proteobacteria, } \\
\text { Bacteroidetes, } \\
\text { Firmicutes, } \\
\text { Actinobacteria, } \\
\text { Methanobacterium, } \\
\text { Methanocalculus }\end{array}$ & $\begin{array}{l}\text { Pelican lake } \\
\text { oil field }\end{array}$ & $\begin{array}{l}18 \\
\sim \\
20\end{array}$ & $\begin{array}{l}\text { E-Proteobacteria } \\
\text { Methanomicrobiales } \\
\text { Methanosarcinales }\end{array}$ & $\begin{array}{l}\text { Grabowski et } \\
\text { al. }(2005)\end{array}$ \\
\hline
\end{tabular}

of the sequences assigned to $\mathrm{CO}_{2}$-reducing methanogens in the present investigation are in line with the view that $\mathrm{CO}_{2}$ reducing methanogens are the most commonly encountered in both cultivation and culture-independent studies of oilfield archaea (Head et al., 2010). Moreover, methanogenesis from acetate driven via syntrophic acetate oxidation has been documented to occur in high-temperature oil reservoirs
(Shestakova et al., 2011) as well as in methanogenic nalkanes degradation enrichment derived from production water of high-temperature oil reservoirs (Mbadinga et al., 2012). The high apparent abundance of thermophilic, syntrophic acetate, propionate, isobutyrate and butyrateoxidizing Firmicutes, as well as thermophilic $\mathrm{CO}_{2}$-reducing methanogens, coupled with the transiently high levels 
of corresponding substrate metabolites detected in hightemperature oil reservoirs (Table 1), further demonstrates that syntrophic acetate oxidation is the main methanogenic pathway in a high-temperature petroleum reservoir in situ. In addition to the well-known $\mathrm{CO}_{2}$-reduction pathways, the type of methyl/methanol-utilizing methanogens as the second most common group in the present research contribute significantly to subsurface biogas formation (Strapoc et al., 2011). Although obligate acetate utilizers are represented by small populations of Methanosaeta, the potential contribution of acetate pathways cannot be ignored. In addition, methanogenic archaea vary substantially between reservoirs and appear to be controlled by local geochemical conditions within the reservoirs.

\section{Conclusions}

Overall, physiologically diverse and temperature-dependent microbial communities inhabit petroleum reservoirs. Thermophilic archaea including members of the Thermococcus, Methanothermobacter and Thermoplasmatales as well as bacterial sequences belonging to the phylum Firmicutes, Thermotogae and Thermodesulfobacteria are widely spread in high-temperature petroleum reservoirs. In contrast, archaeal sequences belonging to the genera Methanobacterium, Methanoculleus and Methanocalculus, and bacterial sequences closely related to members of the phylum Proteobacteria appear to be dominant in low-temperature petroleum reservoirs. These observations agree with several investigations, indicating the occurrence of similar microorganisms in related subterranean ecosystems, especially oil reservoirs. Canonical correspondence analysis (CCA) and principal coordinates analysis ( $\mathrm{PCoA})$ showed a consistency between phylogenetic data and physicochemical parameters for the sampled environments. On the basis of the data obtained, methanogenesis via syntrophic acetate oxidation is expected to be the dominant pathway in high-temperature petroleum reservoirs.

Acknowledgements. We thank Hui Li for discussion on correlation analyses. This work was supported by the National Natural Science Foundation of China (Grant No. 41073055) and the NSFC/RGC Joint Research Fund (No. 41161160560).

Edited by: K. Küsel

\section{References}

Abu Laban, N., Selesi, D., Jobelius, C., and Meckenstock, R. U.: Anaerobic benzene degradation by Gram-positive sulfatereducing bacteria, FEMS Microbiol. Ecol., 68, 300-311, 2009.

Altschul, S., Madden, T., Schaffer, A., Zhang, J., Zhang, Z., Miller, W., and Lipman, D.: Gapped BLAST and PSI-BLAST: a new generation of protein database search programs, Nucl. Acids. Res., 25, 3389-3402, 1997.

Bastin, E. S., Greer, F. E., Merritt, C. A., and Moulton, G.: The presence of sulphate reducing bacteria in oil field waters, Science, 63 , 21-24, 1926.

Beeder, J., Torsvik, T., and Lien, T.: Thermodesulforhabdus norvegicus gen. nov., sp. nov., a novel thermophilic sulfatereducing bacterium from oil field water, Arch. Microbiol., 164, 331-336, 1995.

Dahle, H., Garshol, F., Madsen, M., and Birkeland, N.-K.: Microbial community structure analysis of produced water from a hightemperature North Sea oil-field, Antonie van Leeuwenhoek, 93, 37-49, 2008.

De Long, E. F.: Archaea in coastal marine environments, P. Natl. Acad. Sci., 89, 5685-5689, 1992.

De Santis, T. Z., Hugenholtz, P., Keller, K., Brodie, E. L., Larsen, N., Piceno, Y. M., Phan, R., and Andersen, G. L.: NAST: a multiple sequence alignment server for comparative analysis of $16 \mathrm{~S}$ rRNA genes, Nucl. Acids. Res., 34, 394-399, 2006a.

De Santis, T. Z., Hugenholtz, P., Larsen, N., Rojas, M., Brodie, E. L., Keller, K., Huber, T., Dalevi, D., Hu, P., and Andersen, G. L.: Greengenes, a chimera-checked 16S rRNA gene database and workbench compatible with ARB. Appl. Environ. Microb., 72, 5069-5072, 2006b.

Fardeau, M. L., Faudon, C., Cayol, J. L., Magot, M., Patel, B. K. C., and Ollivier, B.: Effect of thiosulphate as electron acceptor on glucose and xylose oxidation by Thermoanaerobacter finnii and a Thermoanaerobacter sp. isolated from oil field water, Res. Microbiol., 147, 159-165, 1996.

Fardeau, M.-L., Ollivier, B., Patel, B. K. C., Magot, M., Thomas, P., Rimbault, A., Rocchiccioli, F., and Garcia, J.-L.: Thermotoga hypogea sp. nov., a xylanolytic, thermophilic bacterium from an oil-producing well, Int. J. Syst. Bacteriol., 47, 1013-1019, 1997.

Gieg, L. M., Duncan, K. E., and Suflita, J. M.: Bioenergy production via microbial conversion of residual oil to natural gas, Appl. Environ. Microb., 74, 3022-3029, 2008.

Good, I. J.: The population frequencies of species and the estimation of population parameters, Biometrika, 40, 237-264, 1953.

Grabowski, A., Nercessian, O., Fayolle, F., Blanchet, D., and Jeanthon, C.: Microbial diversity in production waters of a lowtemperature biodegraded oil reservoir, FEMS. Microbiol. Ecol., 54, 427-443, 2005.

Gray, N. D., Sherry, A., Grant, R. J., Rowan, A. K., Hubert, C. R. J., Callbeck, C. M., Aitken, C. M., Jones, D. M., Adams, J. J., Larter, S. R., and Head, I. M.:The quantitative significance of Syntrophaceae and syntrophic partnerships in methanogenic degradation of crude oil alkanes, Environ. Microbiol., 13, 29572975, 2011.

Guan, J., Xia, L.-P., Wang, L.-Y., Liu, J.-F., Gu, J.-D., and $\mathrm{Mu}$, B.-Z.: Diversity and distribution of sulfate-reducing bacteria in four petroleum reservoirs detected by using $16 \mathrm{~S}$ rRNA and $d s r A B$ genes, Int. Biodeterior. Biodegrad., 1-9, doi:10.1016/j.ibiod.2012.06.021, 2012. 
Hattori, S., Kamagata, Y., Hanada, S., and Shoun, H.: Thermacetogenium phaeum gen. nov., sp. nov., a strictly anaerobic, thermophilic, syntrophic acetate-oxidizing bacterium, Int. J. Syst. Evol. Microbiol., 50, 1601-1609, 2000.

Head, I. M., Larter, S. R., Gray, N. D., Sherry, A., Adams, J. J., Aitken, C. M., Jones, D. M., Rowan, A. K., Huang, H., and Röling, W. F. M.: Hydrocarbon degradation in petroleum reservoirs, in: Handbook of Hydrocarbon and Lipid Microbiology, edited by: Timmis, K. N., Springer, Berlin Heidelberg, 30973109, 2010.

Huber, T., Faulkner, G., and Hugenholtz, P.: Bellerophon: a program to detect chimeric sequences in multiple sequence alignments, Bioinformatics, 20, 2317-2319, 2004

Imachi, H., Sekiguchi, Y., Kamagata, Y., Hanada, S., Ohashi, A., and Harada, H.: Pelotomaculum thermopropionicum gen. nov., sp. nov., an anaerobic, thermophilic, syntrophic propionateoxidizing bacterium, Int. J. Syst. Evol. Microbiol., 52, 17291735, 2002.

Jeanthon, C., Reysenbach, A.-L., L'Haridon, S., Gambacorta, A., Pace, N., Glénat, P., and Prieur, D.: Thermotoga subterranea sp. nov., a new thermophilic bacterium isolated from a continental oil reservoir, Arch. Microbiol., 164, 91-97, 1995.

Jones, D. M., Head, I. M., Gray, N. D., Adams, J. J., Rowan, A. K., Aitken, C. M., Bennett, B., Huang, H., Brown, A., Bowler, B. F. J., Oldenburg, T., Erdmann, M., and Larter, S. R.: Crudeoil biodegradation via methanogenesis in subsurface petroleum reservoirs, Nature, 451, 176-180, 2008.

Kolganova, T. V., Kuznetsov, B. B., and Turova, T. P.: Selection and testing of oligonucleotide primers for amplification sequencing of archaeal 16S rRNA genes, Mikrobiologiya, 71, 283-285, 2002

Li, H., Yang, S.-Z., Mu, B.-Z., Rong, Z.-F., and Zhang, J.: Molecular analysis of the bacterial community in a continental hightemperature and water-flooded petroleum reservoir, FEMS Microbiol. Lett., 257, 92-98, 2006.

Li, H., Yang, S.-Z., and Mu, B.-Z.: Phylogenetic diversity of the archaeal community in a continental high-temperature, waterflooded petroleum reservoir, Curr. Microbiol., 55, 382-388, 2007a.

Li, H., Yang, S.-Z., Mu, B.-Z., Rong, Z.-F., and Zhang, J.: Molecular phylogenetic diversity of the microbial community associated with a high-temperature petroleum reservoir at an offshore oilfield, FEMS Microbiol. Ecol., 60, 74-84, 2007b.

Li, H., Chen, S., Mu, B.-Z., and Gu, J.-D.: Molecular detection of anaerobic ammonium-oxidizing (anammox) bacteria in high temperature petroleum reservoirs, Microb. Ecol., 60, 771-783, 2010.

Li, H., Mu, B.-Z., Jiang, Y., and Gu, J.-D.: Production processes affected prokaryotic amoA gene abundance and distrubution in high-temperature petroleum reservoirs, Geomicrobiol. J., 28, 692-704, 2011.

Li, W., Wang, L.-Y., Duan, R.-Y., Liu, J.-F., Gu, J.-D., and Mu, B.-Z.: Microbial community characteristics of petroleum reservoir production water amended with $n$-alkanes and incubated under nitrate-, sulfate-reducing and methanogenic conditions, Int. Biodeterior. Biodegrad., 69, 87-96, 2012.

Lozupone, C. and Knight, R.: UniFrac: a new phylogenetic method for comparing microbial communities, Appl. Environ. Microb., 71, 8228-8235, 2005.
Mbadinga, S. M., Wang, L.-Y., Zhou, L., Liu, J.-F., Gu, J.-D., and $\mathrm{Mu}, \mathrm{B} . \mathrm{Z} . \mathrm{A}$ Microbial communities involved in anaerobic degradation of alkanes, Int. Biodeterior. Biodegrad., 65, 1-13, 2011.

Mbadinga, S. M., Li, K.-P., Zhou, L.,Wang, L.-Y., Yang, S.-Z., Liu, J.-F., Gu, J.-D., and Mu, B.-Z.: Analysis of alkane-dependent methanogenic community derived from production water of high temperature petroleum reservoir, Appl. Microbiol. Biot., 96, 531-542, doi:10.1007/s00253-011-3828-8, 2012.

Nazina, T. N., Shestakova, N. M., Grigor'yan, A. A., Mikhailova, E. M., Tourova, T. P., Poltaraus, A. B., Feng, C.-X., Ni, F.-T., and Belyaev, S. S.: Phylogenetic diversity and activity of anaerobic microorganisms of high-temperature horizons of the Dagang oil field (P. R. China), Microbiology, 75, 55-65, 2006.

Nilsen, R. K., Torsvik, T., and Lien, T.: Desulfotomaculum thermocisternum sp. nov., a sulfate reducer isolated from a hot North Sea oil reservoir, Int. J. Syst. Evol. Microbiol., 46, 397-402, 1996.

Orphan, V. J., Taylor, L. T., Hafenbradl, D., and Delong, E. F.: Culture-dependent and Culture-independent characterization of microbial assemblages associated with high-temperature petroleum reservoirs, Appl. Environ. Microb., 66, 700-711, 2000.

Orphan, V. J., Goffredi, S. K., Delong, E. F., and Boles, J. R.: Geochemical influence on diversity and microbial processes in high temperature oil reservoirs, Geomicrobiol. J., 20, 295-311, 2003.

Parkes, J.: Cracking anaerobic bacteria, Nature, 401, 217-218, 1999.

Pham, V. D., Hnatow, L. L., Zhang, S., Fallon, R. D., Jackson, S. S., Tomb, J-F., Delong, E. F., and Keeler, S. J.: Characterizing microbial diversity in production water from an Alaskan mesothermic petroleum reservoir with two independent molecular methods, Environ. Microbiol., 11, 176-187, 2009.

Ravot, G., Magot, M., Fardeau, M.-L., Patel, B. K. C., Prensier, G., Egan, A., Garcia, J.-L., and Ollivier, B.: Thermotoga elfii sp. nov., a novel thermophilic bacterium from an African oilproducing well, Int. J. Syst. Evol. Microbiol., 45, 308-314, 1995.

Ravot, G., Magot, M., Fardeau, M.-L., Patel, B. K. C., Thomas, P., Garcia, J.-L., and Ollivier, B.: Fusibacter paucivorans gen. nov., sp. nov., an anaerobic, thiosulfate-reducing bacterium from an oil-producing well, Int. J. Syst. Evol. Microbiol., 49, 1141-1147, 1999.

Rees, G. N., Grassia, G. S., Sheehy, A. J., Dwivedi, P. P., and Patel, B. K. C.: Desulfacinum infernum gen. nov., sp. nov., a thermophilic sulfate-reducing bacterium from a petroleum reservoir, Int. J. Syst. Evol. Microbiol., 45, 85-89, 1995.

Saitou, N. and Nei, M.: The neighbor-joining method: a new method for reconstructing phylogenetic trees, Mol. Biol. Evol., 4, 406425, 1987.

Sekiguchi, Y., Kamagata, Y., Nakamura, K., Ohashi, A., and Harada, H.: Syntrophothermus lipocalidus gen. nov., sp. nov., a novel thermophilic, syntrophic, fatty-acid-oxidizing anaerobe which utilizes isobutyrate, Int. J. Syst. Evol. Microb., 50, 771779, 2000.

Shestakova, N. M., Ivoilov, V. S., Tourova, T. P., Belyaev, S. S., Poltaraus, A. B., and Nazina, T. N.: Which microbial communities are present? Application of clone libraries: Syntrophic acetate degradation to methane in a high-temperature petroleum reservoir-culture-based and 16S rRNA genes characterisation, in: Applied Microbiology and Molecular Biology in Oilfield Systems, edited by: Whitby, C., and Skovhus, T. L., Springer, 
Netherlands, 45-53, 2011.

Suflita, J. M., Davidova, I. A., Gieg, L. M., Nanny, M., and Prince, R. C.: Anaerobic hydrocarbon biodegradation and the prospects for microbial enhanced energy production, in: Studies in Surface Science and Catalysis, edited by: Rafael, V. D., and Rodolfo, Q.R., Elsevier, Amsterdam, The Netherlands, 283-305, 2004.

Tamura, K., Peterson, D., Peterson, N., Stecher, G., Nei, M., and Kumar, S.: MEGA5: Molecular evolutionary genetics analysis using maximum likelihood, evolutionary distance, and maximum parsimony methods, Mol. Biol. Evol., 28, 2731-2739, 2011.

ter Braak, C. J. F. and Šmilauer, P.: CANOCO Reference manual and CanoDraw for Windows User's guide: Software for Canonical Community Ordination (version 4.5), Microcomputer Power, Ithaca NY, USA, 2002.

Voordouw, G., Armstrong, S., Reimer, M., Fouts, B., Telang, A., Shen, Y., and Gevertz, D.: Characterization of 16S rRNA genes from oil field microbial communities indicates the presence of a variety of sulfate-reducing, fermentative, and sulfide-oxidizing bacteria, Appl. Environ. Microb., 62, 1623-1629, 1996.
Wang, L.-Y., Mbadinga, S.-M., Li, H., Liu, J.-F., Yang, S.-Z., and $\mathrm{Mu}$, B.-Z.: Anaerobic degradation of petroleum hydrocarbons and enlightenment of the prospects for microbial bio-gasification of residual oil, Microbiology, 37, 96-102, (in Chinese with English abstract) 2010.

Wang, L.-Y., Gao, C.-X., Mbadinga, S.-M., Zhou, L., Liu, J.F., Gu, J.-D., and Mu, B.-Z.: Characterization of an alkanedegrading methanogenic enrichment culture from production water an oil reservoir after 274 days of incubation, Int. Biodeterior. Biodegrada., 65, 444-450, 2011.

Wang, Q., Garrity, G. M., Tiedje, J. M., and Cole, J. R.: Naive bayesian classifier for rapid assignment of rRNA sequences into the new bacterial taxonomy, Appl. Environ. Microb., 73, 52615267, 2007.

Zhou, L., Li, K.-P., Mbadinga, S.-M., Yang, S.-Z., and Mu, B.-Z.: Analyses of $n$-alkanes degrading community dynamics of a hightemperature methanogenic consortium enriched from production water of a petroleum reservoir by a combination of molecular techniques, Ecotoxicology, 21, 1680-1691, 2012. 